\title{
Can We Put an End to Commercial Sex?
}

\author{
Wood Lansen* \\ Division of Medicine and Public Health (DMPH), The BASE, Chapel Hill, NC 27510, USA \\ *: All correspondence should be sent to: Dr. Wood Lansen. \\ Author's Contact: Wood Lansen, PhD, E-mail: wood.lansen@basehq.org \\ DOl: https://doi.org/10.15354/si.22.c0008 \\ The author declares no competing interest.
}

\begin{abstract}
Sex workers contend that the emergence of the sex business may be traced back to the pursuit of commercial profits. Several economic issues, including economic inequality, according to sex workers, are at the basis of commercial sexual activity. The sex industry and demand are irreplaceable, which indicates that commercial sex will remain in existence indefinitely.
\end{abstract}

Keywords: Commercial Sex; Economic Inequality; Supply and Demand; Reasons

Science Insights, 2022 February 28; Vol. 40, No. 3, pp.433-434.

(c) 2022 Insights Publisher. All rights reserved.

Creative Commons Non Commercial CC BY-NC: This article is distributed under the terms of the Creative Commons Attribution-NonCommercial 4.0 License which permits non-commercial use, reproduction and distribution of the work without further permission provided the original work is attributed by the Insights Publisher.

$\mathrm{S}$ EX as the sole natural method of reproduction for a species is inextricable and unavoidable (1). However, sex does not exist just for the purpose of reproduction. Sexual enjoyment is one of the hidden uses of sex in humans (2).

Sex can help set the mood, strengthen love, alleviate stress, and promote health in a typical married life (3). However, when sex is inappropriately employed for commercial gain, it acquires trade value. As a result, sex workers emerged. From a historical perspective, the sex industry should be a long-established "profession." Sex workers cannot always be removed, and some are even legalized in some countries (4).

While there are dozens of reasons for engaging sex workers from the perspective of sex workers, ultimately, all of them may be attributed to commercial sex. There must be a reason behind this. Economic factors account for the great majority of people who engage in commercial sex (5). It is not difficult to comprehend the critical role of "economic basis" in the devel- opment of values and life. Additionally, one may argue that economic inequality is at the root of commercial sexual activity. As a result, commercial sex cannot be eradicated as long as there is an imbalance in the development of separate economies.

Additionally, from the perspective of non-sex workers, the presence and development of commercial sexual behavior is ultimately contingent upon the existence of a market with an unmet need, which necessitates the emergence of a supply (6). We cannot suppress our desire for sex because it is a necessary component of our existence. And when individuals are dissatisfied with the sex they have acquired, they might seek external commercial sexual services. As a result, the existence of this market for extra sex demand is another possible source of an unending supply of commercial sex.

In short, the commercial sex industry and demand cannot be replaced, which also means that commercial sex cannot be eliminated. 


\section{References}

1. Ryder JA. The origin of sex through cumulative integration, and the relation of sexuality to the genesis of species. Proc Am Philos Soc 1890; 28(132):109-159.

2. Randolph ME, Pinkerton SD, Bogart LM, Cecil H, Abramson PR. Sexual pleasure and condom use. Arch Sex Behav 2007; 36(6):844-848. DOI: https://doi.org/10.1007/s10508-007-9213-0

3. Liu H, Waite LJ, Shen S, Wang DH. Is Sex Good for Your Health? A National Study on Partnered Sexuality and Cardiovascular Risk among Older Men and Women. J Health Soc Behav 2016; 57(3):276-296. DOI: https://doi.org/10.1177/0022146516661597

4. Ross MW, Crisp BR, Månsson SA, Hawkes S. Occupational health and safety among commercial sex workers. Scand J Work Environ Health 2012; 38(2):105-119. DOI:

https://doi.org/10.5271/sjweh.3184

5. Institute for Women's Policy Research. The Economic Drivers and Consequences of Sex Trafficking in the United States. Last accessed: February 26, 2022. Available at:

https://iwpr.org/iwpr-publications/briefing-paper/the-e conomic-drivers-and-consequences-of-sex-trafficking -in-the-united-states/

6. Gerassi L. A Heated Debate: Theoretical perspectives of sexual exploitation and sex work. J Sociol Soc Welf 2015; 42(4):79-100.

Received: January 06, 2022

Revised: January 17, 2022

Accepted: January 25, 2022 